\title{
Status and socio-ecological dimensions of sacred groves in Northeast India
}

\author{
Keshav Kumar Upadhyay* \\ Department of Forestry, Mizoram University, Aizawl- 796004 (Mizoram), India \\ Bakerbha Japang \\ Department of Forestry, Mizoram University, Aizawl- 796004 (Mizoram), India \\ Ngangbam Somen Singh \\ Department of Forestry, Mizoram University, Aizawl- 796004 (Mizoram), India \\ S.K. Tripathi \\ Department of Forestry, Mizoram University, Aizawl- 796004 (Mizoram), India \\ *Corresponding author. E-mail: upadhyay_keshav@yahoo.co.in
}

\begin{abstract}
Sacred groves are among one of the best practices of biodiversity conservation used by the ethnic societies which are deeply associated with the religion and culture that significantly nurture nature. As these practices play a vital role in conserving socio-ecologically important species and protect threatened flora and fauna from extinction in different ecological zones. In northeast India, sacred groves are well connected with culture and society through religious beliefs of the population and their associated myths. Sacred groves cover a total of $>40,000$ hectares of natural forest area in the five northeastern states of India. These forests house some of the most important and highly threatened species of plants. Wild relatives of present-day cultivated plants are found in these forests and hence act as the gene pool for these species. Social transformation and urbanization have a large impact on the structure and health of these forests and responsible for their destruction. Developmental projects like railways, roads, hydro-electric projects etc. have reportedly destroyed many groves in the past. Due to social transformation, the rate of activities like grazing, encroachment, cutting and collection of fuel wood, fruits and leaves has been increasing and posing a threat to the conservation of biodiversity and ecosystem function in the future. Creating awareness about the social and ecological benefits of maintaining sacred groves among local people, especially youth, can help in reviving these practices and conserving them as a natural heritage for future generations is the need of the hour.
\end{abstract}

Keywords: Northeast, Natural beliefs, Sacred groves, Social Transformation, Threats

\section{INTRODUCTION}

Climate change is one of the burgeoning catastrophes witnessed in the history of mankind, which has resulted in a significant increase in the levels of atmospheric temperature, $\mathrm{CO}_{2}$ and other greenhouse gases. The climate change phenomena are associated with the rising atmospheric temperatures, erratic rainfall patterns, melting of glaciers at faster rates, increasing levels of seashores which are hindering the ecosystems process in almost all kind of ecosystems (Garg . 2015). This can create the situation of natural disasters in different parts of the world and take a heavy toll on human life in times to come. Biodiversity conservation in the diverse range of ecosystems has the potential to mitigate the negative effects of ongoing environmental crises. Religion has always cherished a special place in human society. Connecting things with faith is the easiest way to get society's sup-

\section{Article Info}

https://doi.org/

10.31018/jans.v11i3.2121

Received: May 30, 2019

Revised: July 26, 2019

Accepted: August 14, 2019

\section{How to Cite}

Upadhyay, K.K. et al. (2019). Status and socioecological dimensions of sacred groves in Northeast India. Journal of Applied and Natural Science, 11 (3): $590-595$ https:// doi.org/10.31018/ jans.v11i3.2121 port for a good cause. Sacred groves are the best example of connecting nature with faith (Untawale, 1998; Kulkarni, 2018). They have been used for cultural or spiritual practices by people living in the vicinity. Such sacred forests are found throughout the world and nicely protected and managed by the local communities for the welfare of society. The major activities of the sacred groves are, for example, a place for spiritual activities, burial ground and watershed management (Ormsby, 2013; Amirthalingam, 2016).

Sacred groves are the form of the landscape consist of flora, fauna and geographical features defined and protected by communities and kept under undisturbed condition to express the link between divinity and nature (Hughes and Chandran, 1998). The concept predated to huntinggathering period and flourished in most parts of India (Gadgil and Vartak, 1975). Natural resource conservation has been an integral part of many 
Upadhyay, K.K. et al. / J. Appl. \& Nat. Sci. 11(3): 590- 595 (2019)

Table 1. Distribution of sacred groves and their area in different parts of Northeast India.

\begin{tabular}{|c|c|c|c|c|}
\hline Location & $\begin{array}{l}\text { Total Number of } \\
\text { sacred groves }\end{array}$ & $\begin{array}{l}\text { Number of } \\
\text { deities }\end{array}$ & Area (ha) & References \\
\hline \multicolumn{5}{|l|}{ Arunachal Pradesh } \\
\hline Total & 101 & 46 & 30834 & Khan , 2007 \\
\hline \multicolumn{5}{|l|}{ Assam } \\
\hline KarbiAnglong & 17 & NA & 226 (11 sites) & \\
\hline North Cachar Hills & 12 & NA & NA & \\
\hline Total & 27 & & & Medhi and Borthakur, 2013 \\
\hline \multicolumn{5}{|l|}{ Manipur } \\
\hline Bishnupur & 22 & 19 & 5.78 & \\
\hline Imphal East & 38 & 25 & 54.75 & \\
\hline Imphal West & 98 & 85 & 112.65 & \\
\hline Thoubal & 8 & 3 & 2.2 & \\
\hline Total & 166 & 132 & 175.38 & Khumbongmayum, 2005 \\
\hline \multicolumn{5}{|l|}{ Meghalaya } \\
\hline East Garo Hills & 8 & NA & 125 & \\
\hline East Khasi Hills & 50 & NA & 5129 & \\
\hline Jaintial Hills & 15 & NA & 916 & \\
\hline Ri Bhoi & 3 & NA & 1080 & \\
\hline West Garo Hills & 8 & NA & 181 & \\
\hline West Khasi Hills & 21 & NA & 1864 & \\
\hline Total & 105 & & 9295 & Tiwari, 1999 \\
\hline \multicolumn{5}{|l|}{ Sikkim } \\
\hline Total & 19 & 15 & $\mathrm{NA}$ & Anonymous, 2011 \\
\hline
\end{tabular}

indigenous communities and forest patches were traditionally conserved by dedicating them to local deities known as sacred groves. These Sacred groves are believed to be the living place of deities and spirits of the hamlets who protect villagers from calamities and bring prosperity (Patnaik and Pandey, 1998). In return, the villagers propitiate them through rituals and sacrifice during festivals or designated seasons. These forest pockets are generally protected near to virgin and degree of activities allowed according to sacredness. In Khasi and Garo tradition, human interference is completely prohibited, whereas Gonds of central India allow the collection of fallen parts and prohibits the cutting of the tree.

India, a country with diverse cultural and natural heritage, is believed to have the highest number of sacred groves estimated $\sim 100,000$ (Malhotra, 2007). In most parts of India, Sacred grooves represent the climax vegetation, which is disappearing due to changes in faith, increasing anthropogenic pressure and modernization of society (Chandrakanth, 2004). Sacred groves are the best examples of a traditional way of in-situ conservation and averting an ecological crisis. Although the preservation of sacred grooves is based on religious belief, they are important for germplasm conservation, which is otherwise under threat due to anthropogenic activities (Boojh and Ramakrishna, 1983). This traditional practice of biodiversity conservation evolved by devout people stand as a lesson to the present-day foresters.

The present paper reviewed the sacred groves of five northeastern states of India, highlighting their cultural (religious affiliation) and natural heritage (area covered for biodiversity conservation). It is emphasizing the importance of sacred groves to the environment as well as society and pointing out the possible threats. The information will be helpful in making better strategies for management of sacred groves and utilizing the concept for biodiversity conservation.

Demography of Northeast India: The northeast region of India has a very high diversity in terms of cultural and natural resources (Fernandes, 2006). The region is comprised of states like Arunachal Pradesh, Assam, Manipur, Meghalaya, Mizoram, Nagaland, Sikkim and Tripura (Figure 1). The Siliguri corridor connects it with the rest of the country. These states share their international borders with other countries like Bhutan, Myanmar, China and Bangladesh. The region is the part of two biodiversity hotspots viz. Eastern Himalaya and Indo-Burma. It has a total geographical area of about2, 62, 230 $\mathrm{km}^{2}$ that makes 9 percent of the total landmass of the country (Joshi ., 2015). The region has approximately 40 million populations according to the population census of 2011.Majority of the land mass (i.e. 65.60 percent) is under forest cover. The climate 
Upadhyay, K.K. et al. / J. Appl. \& Nat. Sci. 11(3): 590- 595 (2019)

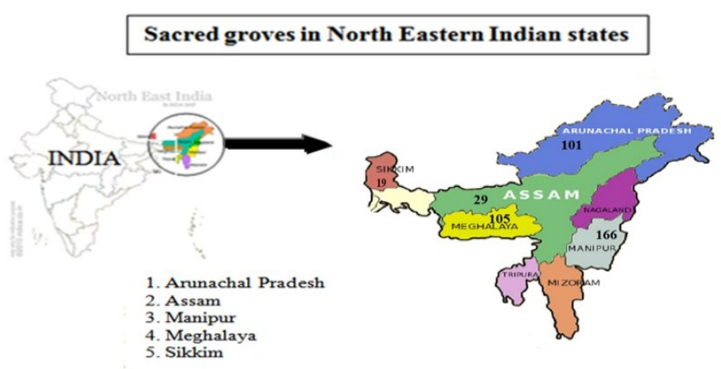

Fig. 1. Map of Northeast India showing numbers of sacred groves in North Eastern Indian states.

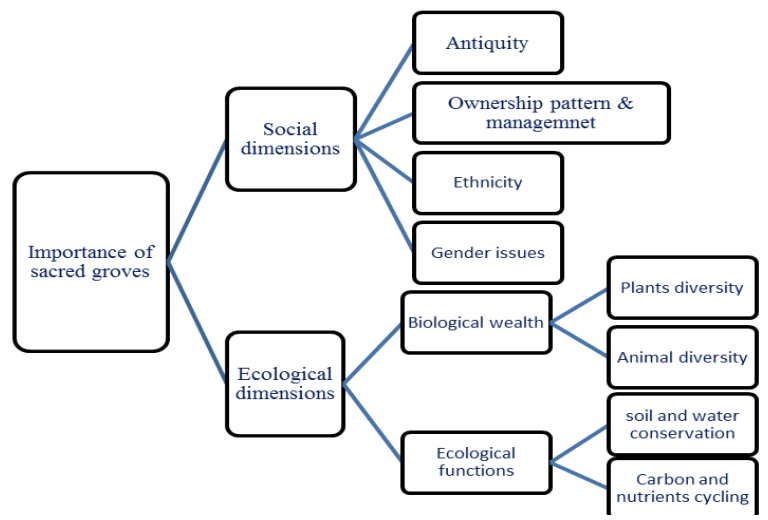

Fig. 2. Social and ecological dimensions of sacred groves in North Eastern Indian states.

of the area ranges from tropical humid in the lower plains to cold temperate in higher ridges of eastern Himalaya (Fernandes, 2006; Burman, 1992).

Sacred groves in Northeast India: Northeast region is highly diverse in culture, traditional knowledge and biological resources. The region is inhabited by more than 150 tribes using different languages and traditions, which makes it unique in the country (Dutta and Dutta, 2005). These ethnic communities have a strong belief in nature and natural forces. The people have been protecting the plants, including trees, herbs and shrub along with animals and birds. A high number of sacred groves are reported from states of Arunachal Pradesh, Manipur, Meghalaya and parts of Assam (Tripathi, 2001). These groves are known by different names in different ethnic groups. The term 'Than' is used by Bodo and Rabha and 'Madaico' by Dimasa in Assam; 'Umanglai' by Meitei/Meetei in Manipur; 'Law kyntang' or 'Law Lyngdoh' in Meghalaya (Tiwari, 1999; Devi, 2000; Medhi and Borthakur, 2013). Sacred groves of Arunachal Pradesh are mainly managed by Mompa and Lamas. These groves are located at higher altitudes and associated with Buddhist monasteries. The sacred groves of Assam are found in plain as well as foothill regions alongside river valleys and managed by ethnic groups like Bodo, Rabha, Karbi Anglong (Malhotra, 2001). In Manipur, the highest numbers of sacred groves are reported (Figure 1) from four plain districts (Imphal East, Imphal West, Thoubal and Bishnupur). The name

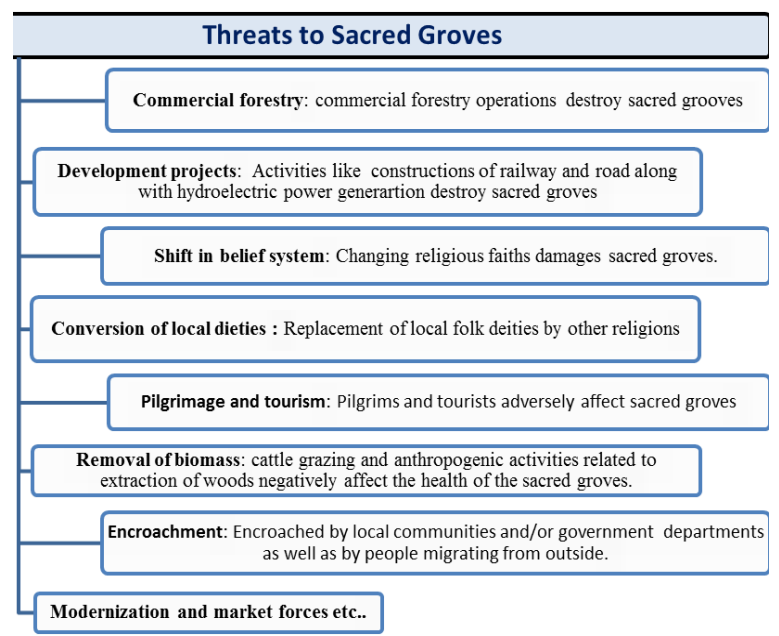

Fig. 3. Various threats available to sacred groves in North Eastern Indian states.

of 'Umanglai' (deity) changes with the community and groves can be seen as a patch of forest on the side of the villages or locality in the plain areas of Manipur (Kulachandra, 1963; Khumbongmayum,2005).

Sacred groves of Arunachal Pradesh: The sacred groves of Arunachal Pradesh are mostly managed by Buddhist monasteries and known as Gumpa forest areas. These protected forests are mainly found in different places of West Kameng and Tawang district. Chatterjee, (2000) reported the presence of sacred grooves in Siang and Lower Sibansari district also. A total of 101 groves (Table 1) have been reported in different places of the state and most of them were attributed to Buddhism (Khan, 2007). These ethnic communities have conserved and protected flora and fauna due to their respect and belief in nature and natural forces and a variety of plants were considered as sacred including Harada, Banyan, Ashoka, Bela and Pipal (Khan, 2007).

Sacred groves of Assam: In Assam, sacred groves managed by Bodo and Rabha ethnic group and Dimasa ethnic group are locally known as 'Than' and 'Madaico' respectively. There are about 29 sacred groves (Table 1) reported from Assam and out of which 17 have been reported in Karbi Anglong district and 12 groves from North Cachar district (Medhi and Borthakur, 2013). Madaico is generally smaller in size with an area less than an acre. Sacred groves are also reported from the Brahmaputra valley of Assam (Malhotra, 2001). Groves like Vaishnav monasteries are distributed almost throughout the state. The plants like giant bamboo, pear bamboo, pink banana, metico pepper, Indian smilax, Areca nut, sand paper tree and Devil's cotton are considered as sacred plants (Amirthalingam, 2016). These groves are associated with the identity of communities to the availability of plant resources. The killing of animals and birds during the mating sea- 
son is prohibited in and around the groves (Medhi and Borthakur, 2013).

Sacred groves of Manipur: In Manipur, sacred groves are commonly known as 'Umanglai'. Sacred groves are worshipped by Meitei/Meetei ethnic tribes annually and celebration is known as 'Umanglai Haraoba'. A total of 365 sacred groves were reported by Devi (2000), and out of these, some groves are a reference for rare and endemic species of plants (Singh, 2001). Among 166 sacred groves (Table 1) reported from four valley areas about $58 \%$ were under partly threatened, $31 \%$ were under threatened and the remaining $11 \%$ were under well protected and preserved category (Khumbongmayum, 2004). Several ecologically important tree species with good soil nutrient retaining capabilities e.g. Alibizia lebbeck, Ficus resemosa, etc. reported from these groves (Khumbongmayum ., 2005). Various developmental activities (viz. roads, highways, buildings) led by increased population pressure and urbanization deteriorating the health of sacred groves (Khumbongmayum, 2004).

Sacred groves of Meghalaya: In Meghalaya, sacred groves are known as 'Law kyntang' and 'Law Lyngdoh' and a total of 105 sacred groves (Table 1) have been reported from different places of east Garo hill, east Khasi hills, Jaintia hills, Ri Bhoi, west Garo hills and west Khasi hills (Tiwari, 1999). Sacred groves of Meghalaya are believed to be the places of the deities by several communities. They bestow their faith in deity for the welfare of their community and crops. Activities like grazing, cutting the tree and their branches, collection of the leaves, flowers, fruits etc. are prohibited in these forest patches and patches are nesting place for birds and other wild animals. As per Jamir and Pandey (2002), about 514 species of flora are reported from these groves belonging to 131 families and 340 genera.

Sacred groves of Sikkim: The sacred groves of Sikkim are mostly attached to Buddhist monasteries and known as Gumpa forests. These forests are protected and managed by lamas. Sacred groves are found in all 4 districts and 19 groves (Table 1) are reported from different locations (Anonymous, 2011). The highlands of Demojong below the Khangchenjunga peak are the most sacred site for the Sikkim's Buddhist. Any human activity here is believed to spell disaster for the region.

Anthropological and biological conservation view of sacred groves: The sacred groves of northeast India have been studied by many with anthropological and biological conservation point (Chandrashekara and Sankar, 1998; Gupta,1998; Pushpangadan, 1998; Ramakrishnan, 1998; Gopal et al., 2019; Rajora and Solanki, 2019). An overview of the socio-ecological dimensions of these sacred groves in North East India is illustrated through the flow diagram in Fig. 2.

Threats to Sacred Groves: In the face of rapid development, great pressure is being placed on ecological and cultural diversity (Xu, 2005). The sacred groves are also facing threats from different developmental changes (Chanda and Ramachandra, 2019). Based on the reports, various threats available to sacred groves are grouped under the different headings and shown in Fig. 3.

\section{Conclusion}

Sacred groves are among one of the important practices which are responsible for conserving endemic flora and fauna of our natural ecosystem, and they promote in-situ conservation of different threatened species. Apart from trees and shrubs, they are home to economically important varieties of orchids, ferns, microbes etc. Sacred groves can act as a genetic pool for forest genetic resources and can be used for future plant improvement programs. Such groves are generally protected by ethnic groups on the basis of religion and culture in the past which are now facing serious decline due to changes in the religious belief of indigenous communities. Several unorganized efforts have been made by different Government agencies and researcher to encourage local communities for the conservation of sacred groves and traditional knowledge but did not get desirable results. There is a need to organize awareness programs for local communities about the importance of sacred groves. Local People especially the youth should be involved and trained in conservation practices. Sacred groves provide a perennial source of drinking water by recharging the springs and important source of medicinal plants, fruits, fuelwood etc. The overexploitation of resources and grazing inside the grove areas has created a threat to various important species. In some parts of northeast India like Meghalaya, steps are being taken up by the Ministry of Environment and Forest to promote conservation of sacred groves through National afforestation and eco-development programs which include proper awareness of local communities towards the conservation of sacred groves. Number of programs for example, fencing sacred groves to reduce grazing and encroachment, promotion of artificial regeneration and enrichment planting of indigenous plant species can help in reviving sacred groves in the region.

\section{REFERENCES}

1. Amirthalingam, M. (2016). Sacred Groves of IndiaAn Overview. Int. J. Curr. Res. Biosci. Plant Biol, 3 (4), 64-74. DOI: 10.20546/ijcrbp.2016.304.011

2. Anonymous (2011). Sacred Groves of Sikkim 2011. Retrieved from http://www.sikkimforest.gov.in/ Reports\%20and\%20Publications/SacredGroves/ Sacred\%20Grooves\%20of\%20Sikkim $\% 202011 \%$ 20Edition\%20FEWMD.pdf

3. Boojh, R. and Ramakrishnan, P.S. (1983) Sacred Groves and Their Role in Environmental Conserva- 
tion. In: Strategies for Environmental Management [Souvenir Volume], Department of Science and Environment, Government of Uttar Pradesh,Lucknow,6-8.

4. Burman, R. J. J. (1992). The institution of sacred grove. Journal of the Indian Anthropological Society, 27, 219-238.

5. Chanda, S., and Ramachandra, T. V. (2019). Sacred Groves-Repository of Medicinal Plant Resources: A Review. Research \& Reviews: Journal of Ecology, 8 (1), 12-20.

6. Chandrakanth, M. G., Bhat, M. G. and Accavva, M. S. (2004). Socio-economic changes and sacred groves in South India: Protecting a community-based resource management institution. In Natural Resources Forum (Vol. 28, No. 2, pp. 102-111). Oxford, UK: Blackwell Publishing Ltd. DOI: https:// doi.org/10.1111/j.1477-8947.2004.00077.x

7. Chandrashekara, U. M. and Sankar, S. (1998). Structure and functions of sacred groves: case studies in Kerala. Conserving the sacred for biodiversity management. Oxford and IBH Publishing, New Delhi, India, 323-335.

8. Chatterjee, S., Sastry, A. R. K., Roy, B. N., \& Lahon, R. (2000, January). Sacred groves of Sikkim and Arunachal Pradesh. In Abstract, National Workshop on Community Strategies on the Management of Natural Resources, Bhopal. Indira Gandhi Rastriya Manav Sanghralaya, Bhopal.

9. Devi, S. (2000). Sacred groves of Manipur. Abstract. In National Workshop on Community Strategies on the Management of Natural Resources, Bhopal. Indira Gandhi Rastriya Manav Sanghralaya, Bhopal.

10.Dutta, B. K. and Dutta, P. K. (2005). Potential of ethnobotanical studies in North East India: An overview. Indian Journal of Traditional Knowledge, $4(1): 7-14$

11.Fernandes, W., Chhetri, S., Joseph, S. and Lama, S. (2006). Development-Induced Displacement and Deprivation in West Bengal 1947-2000: A Quantitative and Qualitative Database on Its Extent and Impact. Guwahati: North Eastern Social Research Centre (mimeo).

12.Gadgil M. and Vartak V.D. (1975). Sacred groves of India - a plea of the continuous conservation. Journal of the Bombay Natural History Society 72(2): 313 $-320$

13.Garg, A., Mishra, V., and Dholakia, H. H. (2015). Climate change and India: adaptation GAP (2015) (No. WP2015-11-01). Indian Institute of Management Ahmedabad, Research and Publication Department.

14.Gopal, D., von der Lippe, M., and Kowarik, I. (2019). Sacred sites, biodiversity and urbanization in an Indian megacity. Urban ecosystems, 22(1), 161-172. DOI: https://doi.org/10.1007/s11252-018-0804-4

15.Gupta, A. K., Deshmukh, S. and Gogate, M. G. (1998). Sacred Groves and Biological Diversity: Providing New Dimension to Conservation Issues.

16.Hughes, J. D. and Chandran, M. S. (1998). Sacred groves around the earth: an overview. Conserving the sacred for biodiversity management, 69-86.

17.Jamir, S. A. and Pandey, H. N. (2002). Status of biodiversity in the sacred groves of Jaintia Hills, Meghalaya. Indian Forester, 128(7), 738-744.

18.Joshi, S. R., Banerjee, S., Bhattacharjee, K., Lyngwi, N. A., Koijam, K., Khaund, P. and Nongkhlaw, F. M. (2015). Northeast Microbial Database: a web-based databank of culturable soil microbes from North East
India. Current Science, 1702-1706.

19.Khan, M. L., Arunachalam, A. and Barbhuiya, A. R. (2007). Web-GIS Digital Atlas of the Sacred Groves of the North-East India: Pilot study with Sacred Groves of Arunachal Pradesh. Technical Report. Department of Scientific \& Industrial Research, Ministry of Science \& Technology, Govt. of India (Sanction No. DSIR/Web/TIF026/2004-2005 Dated 31.12. 2004).

20.Khumbongmayum, A. D. (2004). Studies on plant diversity and regeneration of a few tree species in the sacred groves of Manipur (Doctoral dissertation, Ph. D. Thesis, Department of Botany, North-Eastern Hill University, Shillong, Meghalaya, India).

21.Khumbongmayum, A. D., Khan, M. L., \& Tripathi, R. S. (2005). Sacred groves of Manipur, northeast India: biodiversity value, status and strategies for their conservation. Biodiversity \& Conservation, 14(7):1541-82

22.Kulachandra, N. S. (1963). Meitei Lai Harouba: Keisanthong. Unique Printing Network, Imphal.

23. Kulkarni, A., Upadhye, A., Dahanukar, N., and Datar, M. N. (2018). Floristic uniqueness and effect of degradation on diversity: A case study of sacred groves from northern Western Ghats. Tropical Ecology, 59 (1), 119-127.

24.Malhotra, K. C., Gokhale, Y., Chatterjee, S., \& Srivastava, S. (2007). Sacred groves in India: An overview. Aryan Books Internat.

25.Medhi, P. and Borthakur, S. K. (2013). Sacred groves and sacred plants of the Dimasas of North Cachar Hills of Northeast India. African Journal of Plant Science, 7(2), 67-77. DOI: 10.5897/ AJPS12.038

26.Ormsby, A. (2013). Analysis of local attitudes toward the sacred groves of Meghalaya and Karnataka, India. Conservation and Society, 11(2), 187-197. DOI: 10.4103/0972-4923.115722

27.Patnaik, S. and Pandey, A. (1998). A study of indigenous community based forest management system: Sarna (Sacred grove). Conserving the Sacred for Biodiversity Management, 315-321.

28.Pushpangadan, P., Rajendraprasad, M. and Krishnan, P. N. (1998). Sacred groves of Kerala: a synthesis on the state of art of knowledge. Conserving the Sacred for Biodiversity Management. Oxford and IBH publishing Co, New Delhi.

29.Rajora, S., and Solanki, H. (2019). Sacred groves as centres of cultural and biodiversity conservation: a case study of Jhabua district of Madhya Pradesh. International Journal of Recent Scientific Research, 10 (05A), 32209-32214 DOI: http:// dx.doi.org/10.24327/ijrsr.2019.1005.3421

30.Ramakrishnan, P. S. (1998). Conserving the sacred for biodiversity: the conceptual framework. Conserving the sacred for biodiversity management, 3.

31.Singh, R. N. (2001). Biodiversity mapping of sacred groves of Manipur with special references to conservation of few endangered tree species. PhD diss. International Institute of Ecology and Environment, New Delhi.

32.Tiwari, B.K., Barik, S.K. and Tripathi, R.S. (1999). Sacred Forests of Meghalaya, Biological and Cultural Diversity. Regional Centre National Afforestation and Eco-Development Board, North eastern Hill University, Shillong.

33.Tripathi, R. S. (2001). Sacred groves: community 
Upadhyay, K.K. et al. / J. Appl. \& Nat. Sci. 11(3): 590- 595 (2019)

biodiversity conservation model in north-east India. In Tropical ecosystems structure, diversity and human welfare (Supplement). Proceedings of the International Conference on Tropical Ecosystems, ATREE, Bangalore (pp. 104-107).

34.Untawale, A.G., Wafar, S. and Warfer, M. (1998). Sacred mangroves in India. Pages 247-252, In: Ramakrishnan, P.S., Saxena, K.G. and Chan- drashekara, U.M. (Editors) Conserving the Sacred for Biodiversity Management. UNESCO and Oxford-IBH Publishing, New Delhi.

35.Xu, J. C., Ma, E. T., Tashi, D., Fu, Y. S., Lu, Z., \& Melick, D. (2005). Integrating sacred knowledge for conservation: cultures and landscapes in southwest China. Ecology and Society 10(2): 7 DOI: 10.5751/ ES-01413-100207 